\title{
Local Government Administration in Nigeria: A Historical Perspective
}

\author{
Oluwatobi O. Adeyemi (PhD) \\ Department of Local Government Studies \\ Obafemi Awolowo University, Ile-Ife, Osun- State, Nigeria. \\ E-mail: funktob@gmail.com
}

Received: Jan. 8, 2019 Accepted: May 13, 2019 Online published: May 21, 2019

doi:10.5296/jpag.v9i2.14813ＵRL: https://doi.org/10.5296/jpag.v9i2.14813

\begin{abstract}
Local government administration in Nigeria is as old as history and its dated back pre-colonial era. It had been part of system of government among ethnic groups in Nigeria particularly the Yoruba in the West, Hausa/Fulani in the North and the Igbo in the East. Each ethnic group operating it as it suits their cultural value. Under colonial administration, it was known as indirect rule system. It was an attempt to govern the people through their chief. At independence and thereafter, the system has since been restructured and reorganized depending on the regime and the nature of government in power. These changes have made it to pass through series of uncertainties and with peculiar characteristics. The paper, therefore, examines the historical development of local government in Nigerian state. The research methodology is carried out through the use of secondary data. However, the paper founds out that, the current state of Local Government in Nigeria is characterised by unbridled interference of the State Government and therefore recommends that, there is need to review the Constitution to make Local Government autonomous especially on the issues of fiscal power, functions and responsibilities.
\end{abstract}

Keywords: local government, local administration, sole administrator, caretaker committees, military

\section{Introduction}

The history of the modern local government in most developing countries has been a tortuous one. It has been an age-long episode of trial and error, a blending of tradition with modernity (Fatile, et al, 2013: 227). In Nigeria, the system of governance at grassroots level did not come with the attainment of nationhood in 1960; neither was it the handiwork of colonial masters. Local governments have always been an integral part of various societies and human 
communities that became known as Nigeria with amalgamation of 1914 by Sir Frederick. In pre-colonial times it revolved around the traditional authority of each locality. It was acknowledged and respected (Ola, 2004:175). Since then, local government has passed through different levels of restructuring from Native Authority System (indirect rule system) to Divisional, District and Council Manager-ship, as well as a system of local government, which was introduced by the 1976 reform. However, since the introduction of 1976 reform, local governments in Nigeria have become a uniform administrative structure.

The paper, therefore, examines the historical development of local government in Nigerian state. In achieving this stated objective, the discourse begins with the introduction, conceptual framework, the historical phases of local government, conclusion and recommendations

\section{Conceptual Framework}

The institution of local government has long been in existence in Nigeria and any other part of the world, but mode of operation and the nomenclature differ from one's political system to the other. Hence, most writers on local government pay little attention to the issue of its definition. This, however, does not allow for uniform agreement on the definition of the concept. The absence of mutually agreed definition may not be explained as arising from vagueness of the idea conveyed by the concept but more significantly because of the series of postulations regarding the reason for the existence and objectives/purpose of local government (Marcellus, 2009). Hence, public administrators and scholars have tried to define it to suit their perception and purpose.

Local government as a form of decentralization can be viewed from two perspectives, which are de-concentration and devolution. When a local government is seen as de-concentration or local administration, it lacks the financial autonomy on its budgetary decision, most of the key officials of its administrative machinery are appointees of state or central government and are accountable to it and for most of the period of its existence do not have council that is democratically elected by the people at the local level. For many years' especially before 1976 local councils in Nigeria were run as a mere administrative outpost of the regional (later states) and Federal Government. In this arrangement local governments were merely appendage of superior level and local administrative units. This means that those who exercise power under this system were serving higher superior authorities either state or central government. Thus, there was no autonomy to enable officer to be innovative and creative. This was the state of local government in Nigeria before 1976 reform and under the recent democratic dispensation where some state operates a Caretaker Committee system as against the democratic elected council that was recommended by 1976 local government reform.

Devolution however refers to decentralisation of both political and administrative powers. So, while, local administration refers to purely and only administrative aspect, local government refers to both political and administrative capabilities. In short, whereas the former lacks initiative, the later has it. Local government in this regard can be seen, as that unit of administration with defined territory and power as well as administrative authority with relative autonomy. From this explanation, it becomes clear that what differentiates local 
government from local administration is the degree of autonomy which such unit enjoys from other level or tiers of government (Ighodalo, 2009). Therefore, in order not to deviate from the conceptual framework. It is important at this juncture to examine some definitions of local government so as to have a clear understanding of the concept.

Sharma and Sadana cited in (Ovaga, http://www.academicexcellencesociety...) defines local government as a statutory authority in a specified local area, having the power to raise revenue through taxes for the performance of local services such as sanitation, education, water supply, etc. Precisely, they see local government as authority constituted by the elected representatives of the local people, which enjoy autonomy from state or central control sufficient to enable it to perform its services adequately. Appadorai (1975) defines it as a government by the popular elected bodies charges with administrative and executives' duties in matters concerning the inhabitants of a particular district or place.

The United Nations Office for Public Administration quoted in (Ola and Tonwe 2009:4) defines local government as a political sub-division of a nation or (in a federal system) state, which is constituted by law and has substantial control of local affairs, including the powers to impose taxes or to exert labour for prescribed purpose. The governing body of such an entity is elected or otherwise locally selected. Contributing further to the discourse, a more encompassing definition of local government and the one that captures the relevant indices of local government is contained in 1976 Guideline for Local Government Reform. According to the Reform, Local government is:

Government at the local level exercised through representative council, established by law to exercise powers within defined areas. These powers should give the council substantial control over local affairs (including staffing) and institutional and financial powers to initiate and direct the provision of service and to determine and implement projects so as to compliment the activities of the state and federal government in their areas, and ensure, through devolution of these functions to these councils and through the active participation of the people and their traditional institutions, that local initiative and response to local needs and conditions are maximized (FGN, 1976)

The above definitions imply that there are essentials distinguishing characteristic of local government which are also well articulated in the scholarly work of many other scholars. These features according to Eme (2009:62) are as follows:

1. Localness: this particular feature implies that local government is the lowest tier of government; it is government at the grassroots or local level. Consequently, local government is subordinate but subservient; to the central/federal or state government.

2. It has a legal existence enshrined in the constitution as in Nigeria. This protects it from arbitrary actions of higher authority. As a legal entity, it can sue or be sued and has a perpetual succession. This implies that the life of a local government does not expire with the end of each administration. 
3. It enjoys substantial autonomy. Although local governments are subject to state or federal government control in certain areas, but they enjoy a reasonable degree of independence in administrative and financial affairs.

4. It exists within a defined territory.

5. Local government exercises its authority over a given population. In other words, as a corporate entity, local government is created to serve citizens resident in a known location.

6. It exercises specific powers and performs certain functions as enshrined in the constitution or statutes (as in Nigeria).

7. The council is composed of elected representatives of local people.

8. Local government is usually divided into departments, divisions or units which facilitates the accomplishment of its goals, objectives and functions.

\section{The Historical Phases of Local Government Adminstration in Nigeria}

Local government system in Nigeria has undergone series of metamorphosis. The system has been restructured and reorganized depending on the regime in power either military or civilian administration. These changes have caused local government to pass through series of uncertainties and with peculiar characteristics which are discussed under various headings as follows:

\section{Nigeria Local Government Administration System During Pre-Colonial Era}

Prior to amalgamation, the pre-colonial societies in Nigeria were made up of empires, a caliphate, kingdoms, chiefdoms, city states and villages with ruler that exercise absolute authority over them as in the case of empire or kingdom in the northern region, the Oba in the West, whose power can be checkmated by constituted authority and the Igbo society in the East with its republic and egalitarian status (Adeyemi, 2018:41). Local administration in Nigeria predated colonial rule as each of the separate entity that make up the nation had a unique but relatively effective system (Alao, et al, 2015). It had been part of a kind systems of government especially at the grassroots level among ethnic groups in Nigeria, particularly among the Yoruba and Fulani. An examination of the three main geographical zones in Nigeria clearly reveals that by the early sixteenth century, the Hausa emirates had developed a well-organised fiscal system, a definite code of land tenure, a regular scheme of local rule through appointed district and village heads, as well as a trained judiciary which administer the Islamic laws (Ola and Tonwe, 2009:69).

In Western part of Nigeria, local rule had also developed around the local rulers (i.e. the Kings or Obas) where they had existed. Though the fiscal system was less rigorously organised as it was characterised by check and balances, there was a definite code of land tenure based on the local ruler who administered it at the will of the lesser chiefs and the general people. There also existed a clear scheme of local rule through the lesser local ruler, his chief and their appointed aides. In this case, the judiciary was not distinct from the executive as in the Hausa states. The basis of justice in the West was also different. It was not 
the Islamic law. It was based on three major factors.

(1) Oral traditions;

(2) Rule of precedence; and

(3) Native Philosophy (Ola and Tonwe, 2009).

The patterns of local rule in the -Eastern part of Nigeria, particularly in the Igbo communities were different from the North and the West. The communities in that part of the country largely were acephalous or stateless societies which had no system of kinship or political headship where authority and power emanated from. The Igbo had no king. Most of the communities were not or less hierarchically structured. Local administration system of governance was carried out by decisions of the age groups, village square meetings and input from individual within community. The Igbo system was democratic than any other system in the pre-colonial Nigeria based on its egalitarian principle. Therefore, local government administration system has always been an integral part and feature of various communities before the introduction of colonial rule in Nigeria

\section{Nigerian Local Government Administration System Under Colonial Rule (1900-1950).}

Under colonial administration, local government was known as Native Administration or Indirect rule system. It was meant to govern the people through the native chief. The idea was to preserve and use the authority of the local rulers, local institutions, traditions and habits rather than attempt to impose totally new unfamiliar ideas from outside. Local development would, thus come about through the delegation of authority to chiefs and through a gradual participation of the citizen (Ola and Tonwe, 2009). Contrary to this view, the use of native traditional rulers by colonialist was not meant to preserve the culture and custom of the natives. Rather, it was meant for the British's economies and administrative convenience advantage to save huge personnel costs that might have arisen by employing British officials to govern these local societies. It must be noted that, right from inception, the structure of local government in Nigeria was basically designed to serve colonial interests and facilitate the exploitation of the Nigerian people and resources.

Indirect rule, in other words, was to be based essentially on the chief; the local ruler. The localization policy was to ensure his firm grip on his local administration, whilst local standards were to be adopted, presumably in the interest of peace. They were to maintain law and order, prevent crimes and apprehend criminals. Law and order were extremely important to British administration as this was crucial to promoting commerce (Ola and Tonwe, 2009). The local administration comprises of four main features, which are:

(1) The British Resident Officer, who direct and control;

(2) The Native Authority usually headed by a Chief and often supported by a council of elder;

(3) The Native Treasury and

(4) The Native Court composed of representatives of the Native Administration. 
The system, was however, generally built on strong chief. The strength of the chiefs varied, from the very strong autocratic ruler of Hausa emirates to the semi democratic chiefs of South-West and to the acephalous and highly decentralised and egalitarian societies of the South-East. On the whole, three types of native authorities could be distinguished during indirect rule era: The Chief; the Chief- in -Council and the Chief and Council.

1. The Chief: Here the Chief was a sole authority, he had all powers and all authority emanated from him. He made all appointments and was responsible to the Resident of the province and to the colonial administration for all local administrative affairs. Many of the Hausa/Fulani emirates fell under this form of local administration in this era.

2. The Chief - in - Council: The Chief in this type of local administration was at liberty to accept or reject the advice of his council. What really differentiated this from the sole authority type of local administration was the existence of the council of chiefs where matters concerning the communities are decided.

3. The Chief and Council: in this case, the Chief had a council of advisers who shared with him the power of decision-making authority. In other word, the council with him were involved in the making of appointments, land, disbursement, expenditures and various priority areas. This type of limited or Constitutional Chief was the more common with the more liberal Chiefs of the Yoruba Kingdom of the South-West at this time.

However, as Omorogiuwa (No Date: 113) argued, by 1930, colonial native administration through indirect rule since 1890 was already cracking. This resulted from the attendant local problems as well as international responses. With the growing pressure of nationalism and international support for de-colonization and democratization, native administration had to give way for change.

\section{Local Government Administration in Nigeria Between 1950 and 1966}

It was obvious by the late 1940s that the native authority system of local administration in Nigeria had stated losing national appeal, educated Nigerians and some of the well-meaning Nigerians had started agitating for a more participatory system of local administration. The second phase of local administration development started in 1950s or thereabout. The first phase was defective for so many reasons among which regulatory rather than executive power was what it had. It had no mandate to provide any social welfare services and consequently engaged only the staff essential for their rudimentary administrative purpose. Another important reason for rejecting indirect rule system was that the affected communities had no strong sense of belonging or self-involvement in the running of local administration.

The Eastern region was the first in 1950 to initiate a radical change in the operation and administration of local government not only in Nigeria but also in the whole of British West-Africa. Generally, the Eastern Region Local Government Ordinance of 1950 created local government structures that closely resembled the English system. A three- tier local government system, with each having independent operation was introduced. The three tiers were County, District and Local council (Agagu, 2004:191). The county councils were responsible for road and customary courts; the district councils provided for health and 
sanitation while local councils were saddled with other petty services (Adeola, 2009:6). Within a short period, however, the operation of Local Government Ordinance of 1950 began to fail in some ways. The first reason was that it was too ambitious. The second reason was that the implementation throughout the region was done without adequate preparation. The third reason was corruption. The fourth reason was that it was too complex to operate by the councillors and staffs (Agagu, 2004).

The Eastern Region Local Government Law of 1955 was promulgated to replace that of 1950 in an attempt to correct the defects. One notable feature of 1955 Law was the restoration of direct authority of the Minister as well as that of the District Officer. The later was to function as a local inspectorate (Wraith 1972). Furthermore, the Law equally transferred the powers and responsibilities of the Regional Authority to the Minister of Internal Affairs who had ministerial responsibility for local government (Gboyega, 1987). Local Government Service Board was also created in July 1956 to serve as an advisory body to the minister on issues, such as local government staffs, employment and condition of service.

The increasing difficulty in understanding the operation of multi-tier system of local government led to the abolition of the upper and lower tiers thus leaving the middle tier, i.e, the district council. With a single tier left, the district council assumed the role of an all-purpose local government, although in some rural areas.

Another major change in the operation of Local Government in Eastern Region came in 1960 when a new Local Government Law was enacted. One of the reasons which prompted this change was the proliferation of local government councils. The 1960 Local Government Law introduced full adult suffrage to replace the indirect and limited mode of election. It also introduced the committee system into the council management particularly finance as well as medical and health committees. The business of the council was to be presided over by an elected chairman. With much wobbling and trial, the first experiment of modern local government administration in the Eastern Region continued until the collapse of First Republic. (Agagu, 2004).

In the West, the Western Region's Local Government Law of 1952 was also enacted. It is pertinent to state here that, the Western Regional experience in local government reform which came in with the 1952 Local Government Law also provided for three local authorities. These were the Divisional, District and Local Councils. This arrangement was similar to the one in the Eastern region except that the communities were allowed to remain together in the councils so created. It was reasoned that the togetherness of the communities must be preserved (Adeola, 2009:6).

The councils had tenure of three years presided over by a paramount Chief designated President, in the area of authority of the council and where there was no paramount Chief, the position of the President was filled by rotation among the recognised chiefs in the area. The Chairman and Vice-Chairman of these councils were elected by their members. One other important feature was the inclusion of finance committee and any other committee that may be deemed necessary, 
Another law was enacted in 1957 to replace the 1952 reform. The 1957 reform abolished the provincial administration. It made detailed review of past amendments and a special provision for inclusion of one and a maximum of six women in a council. In the area of finance, Income Tax Law, which allowed the Councils to collect more of their revenue themselves through rates, replaced the Direct Taxation Ordinance which depended more on a share of the tax collected. As far back as 1957, it was obvious that the experiment in Western Region had run short of expectation just like that of the Eastern Region. The political crisis in the Region between 1962 and 1965, which emanated from the split in the leadership of the Action Group, also contributed immensely to the problems of the operation of local government in the region (Agagu, 2004).

In the Northern Region, the Native Authorities Law of 1954 that could be equated with the reforms in the Eastern and Western Regions, rather than making a radical departure from the past, it only served as a consolidating means. The Emir were still in charge but had to operate through either the Chief-in -Council or Chief -and- Council. Whereas in the Chief-and Council, the traditional ruler retained his full authority; in the Chief-and-Council, the traditional (paramount) ruler must recognise the collective desire of other chiefs. These reforms continued with minor adjustment here and there until the military took over in 1966 (Adeola, 2009).

\section{Local Government Under Military Rule (1966-1976)}

One of the features of the arrival of modern local government was that the functions of local governments in the country were wide ranging, comprising both developmental and non-developmental functions. These functions were so comprehensive that almost every function being performed at regional level had its parallel at local level (Ola and Tonwe, 2009:93). Different types of local government administrative systems were operated in the different states of the country following the 1966 military coup and civil war.

As a result of military intervention in politics, the policy direction at the local level was not that of enlarging the coast of political participation but administrative restructuring and consolidation. The military Governor took a bold step in this direction by appointing Divisional Officers as Sole Administrators. Essentially, this policy drive returned Nigeria to era of full centralisation as the military command is unitary and pyramidal (Adeola, 2009). With the creation of 12 states in 1967 and further administrative realignment, the local councils lost virtually all competent hands to the states which are better positioned to offer good conditions of service (Adeola, 2009).

The Eastern part of Nigeria was at this time the battle ground and so local administration was totally in disarray not to talk of any meaningful development or growth. In the Northern part, as far as 1950, the Northern People Congress (NPC) government headed by Sir Ahmadu Bello had desired the reform, if not complete abolition of Native Authorities. During the same period, NPC also called for abolition of House of Chief in the North and its replacement by an advisory council of Chief. So, the Mid-West and the Western part remained the theatre for local administration dramatic spectacles (Olasupo, 2001:18). 
In the Western State for instance, the Sole Administrator system was adopted, and it was a system supported by force and the emergency situation of the period. It was not meant to perform any meaningful duty other than mobilizing support geared towards the war efforts. This arrangement was later replaced with one tier system of local government under a system known as the Council Manager system. This development led to Agbekoya Riots in Western State in 1968 and 1969 when they protested payment of tax without representation. A circular was issued in January 1971 by Ministry of Local Government equating local government staff with the civil servants on the basis of pay and status. This was meant to encourage qualified personnel to join the local government council.

In the Eastern States, different systems were adopted after the civil war. Essentially the philosophy of local government in war torn areas was a system of centralisation that decentralised powers and functions to headquarters from the centre of state headquarter. The system was described as development administration particularly in the South-Eastern State as well as Bendel State (Agagu, 2004). The aim of Development Administration in this area was to involve the people of the state from grassroots upward in meaningful and productive partnership with central government in matters of social and economic development which were both close and relevant to their needs and could effectively contribute to the general development and progress of the state (Olasupo, 2001a). In the East Central State, Divisional Administration was adopted. This system of local administration was designed primarily to co-ordinate the activities of state government functionaries in the field and at the local government councils in such a way as to ensure proper decentralisation of functions and active participation of local people in general development programme and management of their own affairs under supervision and guidance of the local authority.

In the Northern Region, structural and administrative changes occurred with the creation of states in 1967. The divisional administration and Native Authority system were abolished. In their place were, two-tiered pyramidal structure consisting of a local authority and subordinate district authorities. The Emir's towering image was reduced in the new dispensation (Adeola, 2009). Kano State for instance, the state was divided into eight administrative districts and each was controlled by a civil servant appointed by the military government (Olasupo, 2001a).

According to Agagu (2004:197), the period 1966 to 1976 brought out new experiments in terms of philosophies, structures, innovation and changes throughout the country. These attempts however, still maintained the divergences in the operation of local governments across the country. In spite of the innovation and experiments, local administration still lacked a national focus and the esteemed value system needed to make it play its deserving role in national development.

\section{The 1976 Local Government Reform and Aftermath (1976-1983).}

The negative effect of the influence and control of local government activities by the regional/state and federal governments in the country was immense. So much that, the future of the local government as an institution in the country was threatened. It was a significant development, therefore that a nation- wide reform was embarked upon in 1976 to correct 
these anomalies which the central and regional government had subjected local government to.

Awotokun (2001:44) observes that, local government reform was seen principally as a means of bringing the government closer to the people. It was for this notion that a uniform system known as single tier structure was adopted throughout the country. This uniformity can be easily discerned in terms of:

(1) The function of local governments;

(2) The structure of the local government

(3) The financial resources of the local governments;

(4) Relationships with state governments; and

(5) Law enforcement

The major components or features of the 1976 reform were largely institutional and financial and can be summarised as follows;

- Creation of local government units on a uniform population of criteria of $150,000-800,000$ throughout the country, and with a uniform political/administrative structure.

- Local governments are to be democratically elected by same electorate as done for other units of governments in the federal system.

- Local government responsibilities were articulated and divided into mandatory and optional.

- Local government revenue sources were to comprise the traditional source - rates, fees, fines etc. but also annual transfers from the federal governments and state governments. Specifically, urban local governments were to develop the property rates in several cities where they had not been developed.

- Senior personnel of local governments were to have similar condition of service as those of the state government. Special training programmes were mounted for senior local government management personnel in three of the nation's federal University (Ife, Nsukka and Zaria).

- Virtually all these provisions were incorporated into the nation's 1979 and 1989 constitutions.

The role of traditional rulers was also clearly specified in the reform guidelines. They were to serve in advisory capacity through traditional council. Agagu (2004) also observes that the 1976 Local Government Reforms demonstrated a commitment to new political values nation-wide. It was an essential element of the political transition programme of Mohammed/Obasanjo regime and part of the process of building a solid foundation for return of democratic government. According to him, the Guidelines for Local Government Reform 
of 1976 highlighted some of the aims of establishing the local government system as follows:

(a) To make appropriate services and development activities responsive to local wishes and initiatives by devolving or delegating them to local representative bodies.

(b) To facilitate the exercise of democratic self-government close to the local levels of our society and to encourage initiative and leadership potential;

(c) To mobilise human and material resources through the involvement of the public in their local development

(d) To provide a two-way channel of communication between local communities and government.

The 1976 comprehensive reform were given practical application when in December 1976, nine of the nineteen states (Bendel, Imo. Benue, Rivers, Kwara, Lagos, Ogun, Ondo and Oyo Sates) conducted direct election into the councils. Though, the council elections were marred with low turnout, it was generally agreed that it was a good beginning. The absence of partisan politicking was also addressed as part of the problems (Adeola, 2009). The 1976 Local Government Reforms, in spite of its shortcomings has relative success. Commenting in this, Gboyega (1987:175) depicted thus:

In spite of the shortcoming of the local government system, even after the implementation of the 1976 reforms, it deserves to be repeated that a clear vision of a literal local government system had emerged and that through the gradual acceptation of improvements, the ideal system which was envisage could be more and more closely approximated.

Three years after the 1976 reform was introduced and 13 years after military rule held sway, Nigeria had a transition to civil rule on October 1, 1979. For the first time in the history of Nigeria, the constitution recognizes local government as the third tier of government. For instance, section 7 (1) stated that:

The system of local government by democratically elected local government councils is under this constitution guarantee, the Government of every state shall ensure their existence under a law which provides for the establishments, structure, composition, finance and functions of such councils (FGN, 1979:13).

It must be noted that two aspects of the 1976 reform were imbedded in the 1979 constitutional. The first was the guarantee of a democratic system of local government. This is clearly implanted in section 7 (1) of the 1979 constitution as indicated above. The second provision was that, each local government has a right in the Federation Account just as the Federal Government and the State. According to section 149 (2) of the constitution:

Any amount standing to the credit of the federation account shall be distributed among the federal and state governments, and local 
government councils in each state, on such terms and in such manner as may be prescribed by the National Assembly (FGN, 1979:56).

Local government under the Second Republic witnessed over bearing influence of state governments on their operations and activities. For political reasons, some state governments had to create new local government councils which were neither effective nor efficient in the area of service delivery and provision. So bad was the situation that Agagu (2004:201-201) remarks thus:

Contrary to the provision of the constitution, soon after the governor took over power on October 1, 1979, they proceed to dissolve the various councils and replace them with their own nominees. These nominees were the people drawn from political parties of these governors. The choice of nomination as against elections was borne out of fear that the parties in the various states might lose council elections to rival political parties... a second major maladministration in this respect was the proliferation of local government councils. For instance, in Anambra state the number of local governments rose from 23 to 54; in Bauchi from 16 to 43; in Borno from 17 to 59; in Cross River from 19 to 59; in Ogun from 10 to 30 while in Kaduna from 14 to 70. Even in Ondo State, it was disagreement among the legislators that stalled the creation of new ones... Another major area where many of the state governments failed related to disbursement of funds to local governments. Apart from allocation from the Federation Account, the states were expected to make available to local government councils under their jurisdiction $10 \%$ of their total revenue. The states, however failed to fulfil this obligation. Moreover, the authority that was expected of the local government... was also marred by the constant intervention of the Local Government Service Commission.

The Federal Government through the 1982 Electoral Act redressed the anti-democratic posturing by legislating on the time election must compulsorily hold in all councils. But unfortunately, these were cut short in the following year, when the military overthrew the civilian government headed by Alhaji Shehu Shagari on December 31, 1983.

\section{Local Government in the Aftermath of Second Republic (1983-1999)}

Given the shortcomings that local government administration witness during the Second Republic and with the military rule of Buhari's administration, the existing Local Government Management Committees were dissolved in January 1984. The Federal Military Government appointed Sole Administrators made up of senior civil servants to administer the erstwhile 301 local government councils created by the 1976 Reforms. Expectedly, all the new local governments created between 1979 and 1983 were abolished and restored the number of local governments to 301. Five months into their tenure, Buhari and Idiagbon administration set up a 21-Man Committee headed by Alhaji Ibrahim Dasuki. The objective was to depoliticise local government activities, make it efficient as the third tier of 
government. The term of reference given to the Committee includes:

(i) evolve the most suitable mode of managing the local governments within the context of the present Military Administration;

(ii) re-examine the existing structures, functions and financial resources available to local governments for the performance of those function;

(iii) Look into the accounting/management (staff) problems of Local Governments, including the standardisation of the various departments of the councils.

(iv) Evolve proper place of traditional authorities in Local Governments.

(v) Propose how best to manage intergovernmental relations between Federal, State and Local Governments and also, between Local Governments and Ministry for Local Governments, Local Service Boards/Commissions etc;

(vi) Work out manpower development schemes for all cadres of Local Government staff relevant for improvement of local government administration in the country; and

(vii) Deliberate and recommend on other matters the Committee considers relevant for the improvement of Local Government Administration in the country (Awotokun, 2001:45)

The Committee submitted its report in September 1984, but the report was not made public before the Buhari's regime was overthrown in August 1985 through a military coup. The Babaginda's Administration who succeeded Buhari/Idiagbon's regime however published its white paper on the Report in 1986. The military government accepted the recommendation that the structure of local government introduced in 1976 should be retained. It endorsed the pruning of local councils to the 1976 figure and proposes that a Management Committee should be set up to run the councils.

The Babaginda Administration also began its political transition programme with elections into the local government councils, first on non-party basis in December 1987 and later on party basis in 1990 and later introduced a Sole Administratorship in 1989. The Babaginda's Administration eventually created 149 new Local Governments Council thereby bringing the total to 453 .

The 1991 Local Government Constitutional and Transitional Amendment Decree introduced the Executive Presidential System at the Local Government level, with a complete separation of powers typical of executive presidentialism between independent Legislative made up of the elected councillors and Executive arms of Local Governments. The same decree also enhanced the autonomy of the local government vis-a-vis the state government by transferring a number of the supervisory functions to the local government legislative council. One of such functions was the approval of local government budget. However, General Babaginda embarked on transition programme which could not see the light of the day with the annulment of June 12, election. This development led to establishment of interim government headed by Shonekan. General Sani Abacha later overthrew the Interim National 
Government of Earnest Shonekan that was put in place by Babaginda's Administration and sacked all elected political office holders. At local government level Caretaker Committee was appointed and career officer again became the Secretaries to various local government councils. The Presidential System at local government level was also abolished.

The Abacha's political transition programme was also patterned along that of General Babaginda with its first Local Government elections conducted on non-party basis and the subsequent one on political party basis. The Abacha's Administration embarked on creation of states on local governments across the country, which was eventually characterised crises and strife. Akindele and Olaopa (1998:115-131) remarks of the situation thus:

\section{Even though the relocation of local government council had been made in some places in Nigeria without much problem as it was done in Ekiti State, where the (headquarter) of Ilejemeje local government was shifted from Eda-Oniyo to Iye-Ekiti, it has not been so in Osun and Delta States where such policy had pitched the Ifes against the Modakekes and the Ijaw against Ishekiris respecn tively. Consequent upon which the areas have respectively suffered ... loss of lives and properties which would take over a decade to reverse.}

The Abubakar's Administration that took over power as a result of Abacha's sudden death only spent little time. His government also sacked the elected political office holders and dissolved the five political parties of Abacha regime's transition programme. Abubakar initially appointed Sole Administrator among the civil servants, and later adopted Caretaker Committees made up of appointed members from among the indigenes of the local governments. Sole Administrators were made to serve as Chairmen of these Caretaker Committees. The regime later conducted elections to both National, State and Local Government to usher in the Fourth Republic

\section{Local Government in Nigeria Since 1999- Till Date}

As part of the transition programme from military regime to elected civilian government, local government elections were conducted in 1999 across the country for a three-year term. At the expiration of the tenure of Local Governments in 2002, it was expected that election would be conducted immediately, more so as the country was in a democratic dispensation. Unfortunately, it was not so. While the consistent attempts by state governments to weaken local governments in the country is not yet new, the complacency of the federal government and the possible complicity in the delay of Local Government election is disturbing. The state government all over the country are not interested in conducting election in the Local Councils across the country because the non-conduct of election gave them the absolute control over Local Government machinery in their respective states. It is sad that the state government have failed to appreciate the fact that Local Government is fundamentally an integral part of democracy. They have undermined Section 7(1) of 1999 constitution which guarantees democratically elected Local Government council across the country, only few states had witness election since 1999 till date. The diagram below shows states where election has been conducted from 1999 to 2019. 
Table 1. States' Records of Election into Local Government Councils since the Inception of $4^{\text {th }}$ Republic (1999)

\begin{tabular}{|c|c|c|c|}
\hline & State & Years Elections Were Conducted & $\begin{array}{l}\text { No. of Times Elections were } \\
\text { Conducted }\end{array}$ \\
\hline 1 & Anambra & 2013,2017 & 2 \\
\hline 2 & Ebonyi & 2004, 2010, *2013, 2017 & 4 \\
\hline 3 & Oyo & $2004,2007,2018$ & 3 \\
\hline 4 & Osun & $2004,2007,2018$ & 3 \\
\hline 5 & Ondo & $2004, * 2007,2016,2018$ & 4 \\
\hline 6 & Ekiti & $2004,2009,2015,2018$ & 4 \\
\hline 7 & Ogun & $2004,2007,2012,2016$ & 4 \\
\hline 8 & Kwara & 2004, 2007, 2012, 2017 & 4 \\
\hline 9 & Lagos & 2004, 2008, 2012, 2017 & 4 \\
\hline 10 & Akwa Ibom & 2004, 2008, 2012, 2017 & 4 \\
\hline 11 & Cross River & $2004,2010,2013,2017$ & 4 \\
\hline 12 & Edo & $2004, * 2007,2013,2018$ & 4 \\
\hline 13 & Abia & $2004,2008,2016$ & 3 \\
\hline 14 & Bayelsa & $2004, * 2010,2017$ & 3 \\
\hline 15 & Rivers & 2004, 2011, 2015, 2018 & 4 \\
\hline 16 & Delta & $2004, * 2008,2014,2018$ & 4 \\
\hline 17 & Imo & $2004, * 2008,2018$ & 3 \\
\hline 18 & Benue & 2004, 2007, 2012, 2017 & 4 \\
\hline 19 & Enugu & $2004,2007,2011,2013,2017$ & 5 \\
\hline 20 & Nasarawa & $2004,2009,2014,2018$ & 4 \\
\hline 21 & Kano & $2004,2007,2009,2014,2018$ & 5 \\
\hline 22 & Kastina & $2004,2010,2018$ & 3 \\
\hline 23 & Sokoto & 2004, 2008, 2011, 2016 & 4 \\
\hline 24 & Kebbi & 2004, 2008, 2012, 2017 & 4 \\
\hline 25 & Kogi & 2004, 2008, 2013 & 3 \\
\hline 26 & Taraba & 2004, 2007, 2012, 2017 & 4 \\
\hline 27 & Zamfara & 2004,2012 & 2 \\
\hline 28 & Bauchi & $2004,2008,2018$ & 3 \\
\hline 29 & Yobe & 2004, 2009, 2013, 2017 & 4 \\
\hline 30 & Borno & 2004,2007 & 2 \\
\hline 31 & Plateau & $2004,2008,2014,2018$ & 4 \\
\hline 32 & Kaduna & 2004, 2012, 2018 & 3 \\
\hline 33 & Jigawa & 2004, 2011, 2014, 2017 & 4 \\
\hline 34 & Niger & 2004, 2008, 2011, 2016 & 4 \\
\hline 35 & Adamawa & $2004,2008,2012,2016$ & 4 \\
\hline 36 & Gombe & 2004, 2013, 2017 & 3 \\
\hline 37 & Abuja & $2004,2007,2010,2013,2016$ & 5 \\
\hline
\end{tabular}

*Years in which LG elections were held but councils later dissolved, or elections nullified

\section{Source: Author's Compilation}

Table 1 lends credence to the inconsistency in the councils' electoral system. The cause of this is not far-fetched; the state governments exerted undue control over the councils against the provision of section 7 (1) and 8 of the Constitution, authorizing state to run the affairs with unelected committees in interim while putting in place appropriate arrangements for the 
conduct of fresh poll. This control further reflects in states intermittent dissolution of the council at will even before the three-year tenure recognised by Decree 36 of 1998 Electoral Law (the Basic Constitutional and Transitional Provision) lapses (Adeyeye, 2016:25).

The channels for distributing council funds have also become a bone of contention. When money is allocated to the councils, it does not go directly to the councils. It is deposited in the State/Local Government Joint Account (JAC). At the JAC Committee meeting, the council is a junior partner. There are allegations by local government workers that governors indulge in diverting council allocation through controversial deductions (Our Reporter, 2014). This situation in Nigerian Local Government according to Obasanjo in Olatunji (2016) is such they have been bastardised, battered and encroached upon badly, contrary to the vision and mission of 1976 Local Government Reform.

Obasanjo further observes that; the state governor remained the greatest obstacles to having a virile council because they steal council funds under the pretexts that they have done something on their behalf. As soon as the allocation are released from the Federal allocation, the State Governors simply deduct from the source, whatever amount they claimed were spent on behalf of the local government, thereby rendering them ineffective in performance of their statutory functions (Ashytimex, 2016). Also, Adeyemi (2012:193) observes that manpower development and capacity building in contemporary local government in Nigeria has diminished. The chief executive (Chairman) of local government does not see the need to train the staff rather how to steal the money meant for manpower development and capacity building into his own pocket. The situation has made local governments to perform below expectation in the area of service delivery.

\section{Conclusion and Recommendations}

In this work, attempt has been made to examine the evolutionary trends in Local Government administration and Local Government system in Nigeria. An in-depth analysis of the historical trend of local administration and local government shows that Local Government administration started before the arrival of British colonial government and the study has successfully categorised the trend into phases; the traditional pre-colonial Nigeria ( before the arrival of British colonial government); the colonial phase in which Local Government was referred to as Indirect Rule or Native Authority, 1900-1950; the second phase under colonialism was between 1950 and 1966. Also, with the military intervention in politics in 1966, another phase of local government emerged from 1966 to 1976. The era of 1976 to 1983 witnessed the great Local Government Reform which was meant to address the structure and the operation of Local Government in Nigeria, under this reform the nomenclature of local governance changes from Local Administration to Local Government. The military era of 1983 to 1999 also witnessed some reforms in local government administration. Under this phase, election was conducted into Local Government Council on non-party basis before the birth of the Fourth Republic which run from 1999 till date.

Nigeria's experience in local government administration, whether in military regimes or in democratic era, has clearly shows that local government faces serious challenges in carrying out their mandate in promoting development and provides essential services to the rural 
dwellers. Sadly, local government which is statutorily established to be the closest tier of government to the people is not doing its bidding coupled with the fact that resident population in it is denied the benefits of its existence. The failure of the local governments in the area of services delivery has made the citizens to lose their trust in this level of governance (Adeyemi, 2013).

The current state of Local Government in Nigeria is characterised by unbridled interference of the State Government. In many cases, elected Council Executives are dissolved by State Governments without due process and Caretaker Committee is set up as against the democratically elected council stipulated in the constitution. Successive civilian administrations since 1999 have seriously ignored this constitution provision, thereby making Local Government an appendage of State government.

Other problems confronting this level of governance are the instances of political crisis and incessant injunction arising from court cases over council elections and contestations over the conduct of State Independent Electoral Commissions (SIECs) and; the general boycotting of election by especially major opposition political parties in the state. The State Independent Electoral Commission in most cases do the biding of the state governor by making sure that the party in power win in most cases all the chairmanship seat. This in turn might have some untoward effects on the system. One obvious thing is that national and state politics would continue to determine the direction of development at the local government level. This can only be stopped if adequate autonomy that is backed by law and recognised in the Constitution is granted to this level of governance.

Another area that is worth mentioning is the issue of State/Local Government Joint Account. The law setting up local governments makes provision for establishment of State /Local Government Joint Account Committee in each state. Ordinarily, this is meant to be an avenue for effective disbursement and channelling of funds from Federation Account and States to development projects at local governments level. But in reality, this State/Local Government Joint Account Committees exist as channel for the diversion of local government resources by various state governments.

To address the anomalies in Local Government system in Nigeria, there is need to review the Constitution to make Local Government autonomous especially on the issues of fiscal power, functions and responsibilities. Therefore, both Federal and State government should stop their undue interference on the programmes and activities of local government council. The issue of State/Local Government Joint Account should be scrapped. Rather than advocating for total removal of local government from the constitution, the Constitution should be reviewed to strengthen and guarantee democratic participatory council at the grassroots level in Nigeria by conducting regular election at this level.

\section{References}

Adeola, G. L. (2009). From Native Authority to Local Government: Is there a System of Local Government in Nigeria?" in Akhaine, S. O (ed) Local Government Administration in Nigeria: Old and New Visions, Lagos: Centre for Constitutionalism and Demilitarisation 
Adeyemi, O. (2013). Local Government and the Challenges of Service Delivery: The Nigeria Experience. Journal of Sustainable Development in Africa, 15(7), 84-98.

Adeyemi, O. O. (2012). Corruption and Local Government Administration in Nigeria: A Discourse of Core Issues, European Journal of Sustainable Development, 1(2), European Centre of Sustainable Development. https://doi.org/10.14207/ejsd.2013.v2n3p155

Adeyemi, O. O. (2018). Amalgamation and the Crisis of Governance: The Nigeria Experience. Journal of Public Administration and Governance, 8(3), Macrothink Institute. https://doi.org/10.5296/jpag.v8i3.13390

Adeyeye, M. O. (2016). Governing the Localities: Lessons (UN) Learnt An Inaugural Lecture Delivered at Oduduwa Hall, Obafemi Awolowo University, Ile-Ife, Nigeria, on $22^{\text {nd }}$ March.

Agagu, A. A. (2004). Continuity and Change in Local Government Administration and Politics of Underdevelopment" in Agagu, A.A., \& Ola, R.O.F. (eds) Development Agenda of Nigerians State, Ibadan: Flag (Nigeria) Publisher.

Akindele, S. T., \& Olaopa, O. R. (1998). Local Government Creation and strife in Nigeria: The Causes, Effects and Challenges in Kolawole, D. (ed) Issues in Nigeria Government and Politics, Ibadan: Dekaal Publisher.

Alao, D. O, Osakede, K. O., \& Owolabi, T. Y (2015). Challenges of Local Government in Nigeria: Lessons from Comparative Analysis. International Journal of Development and Economic Sustainability, 3(4), European Centre for Research Training and Development.

Appadorai, A. (1975). The Substance of Politics. New Delhi: Oxford University Press.

Ashytimex. (2016). Obasanjo; In Nigeria, how State Government Defraud Local Governments Accessed online at http://www.flashnews.com.ng/2016/10/12/obasanjo...

Awotokun, K. (2001). Constitutional Roles and Responsibilities of Local Government Councils under Current Dispensation in Orekoya, T., \& Agbugba, T. (eds) Local Government Administration in Nigeria, Vol. 1, Lagos: Pure Language Communication Limited.

Ayo, S. B. (1995). “The Evolution of Local Government System” in Awotokun A. M (ed) New Trend in Nigerian Local Government, Ile-Ife: Department of Local Government Studies, Obafemi Awolowo University.

Eme, O. I. (2009). The Fourth Republic and Local Government Creation" in Akhaine, S. O (ed) Local Government Administration in Nigeria: Old and New Visions, Lagos: Centre for Constitutionalism and Demilitarisation.

Fatile, J., Majekodunmi, A., Oni, A., \& Adejuwon, D. (2013). Issues in Public Administration and Local Government: The Comparative Perspective, Lagos: Concept Publication Limited.

FGN (1976). Guideline for Local Government Reforms, Kaduna: Government Printer.

FGN (1979). The Constitution of the Federal Republic of Nigeria, Lagos: Federal Ministry of Information. 
Gboyegan, A. (1987). Political Values and Local Government in Nigeria, Lagos: Malthouse Press.

Ighadalo, A. (2009). The Third Tier of Government and Democratic Governance in Akhaine, S. O (ed) Local Government Administration in Nigeria: Old and New Visions, Lagos: Centre for Constitutionalism and Demilitarisation.

Marcellus, I. K. (2009). Local Government and Constitutional Elasticity in Akhaine, S. O (ed) Local Government Administration in Nigeria: Old and New Visions, Lagos: Centre for Constitutionalism and Demilitarisation.

Ola, R. O. F (2004). Local Government Theory \& Practice: An Examination of Modernization Efforts in Three Decades of Nigerian Local Government (1975-2003) in Agagu, A.A., \& Ola, R.O.F. (eds) Development Agenda of Nigerians State, Ibadan: Flag (Nigeria) Publisher.

Ola, R. O. F., \& Tonwe, D. A. (2009). Local Administration and Local Government in Nigeria Lagos: Amfitop Books.

Olasupo, F. A. (2001). Evolution of Local Government Administration in Nigeria in Orekoya, T., \& Agbugba, T. (eds) Local Government Administration in Nigeria, Vol. 1, Lagos: Pure Language Communication Limited.

Olasupo, F. A. (2001a). Historical Phases of Local Government in Nigeria in Orekoya, T. and Agbugba, T. (eds) Local Government Administration in Nigeria, Vol. 1, Lagos: Pure Language Communication Limited.

Olatunji, D. (2016). "Local Government Autonomy" accessed online at http://www.vanguardngr.com/2016/06/obasanjo...

Omorogiuwa, P. A. (No Date). Local Government in Nigeria, in Ola, R. F. (ed) Introduction to Nigeria Public Administration, Benin City: Department of Political Science, University of Benin.

Our Reporter (2014). Reforming Local Government for Efficiency" accessed online at http://thenationonlineng.net/reforming-local-government-for -effeciency/

Ovaga, O. H. (No Date). Funding in the Local Government System as a Strategy for Sustainable Rural Development in Nigeria" downloaded fromhttp://www.academicexcellencesociety.com/funding_in_the_local_government_

Wraith, R. (1972). Local Administration in West Africa, London: George Allen and Unwin Ltd.

\section{Copyright Disclaimer}

Copyright for this article is retained by the author(s), with first publication rights granted to the journal.

This is an open-access article distributed under the terms and conditions of the Creative Commons Attribution license (http://creativecommons.org/licenses/by/4.0/). 